University of Louisville

ThinkIR: The University of Louisville's Institutional Repository

Electronic Theses and Dissertations

$5-2021$

\title{
The rise of the nones: religion, leaners, and their connection with partisanship in America.
}

Kevin C. Orr

University of Louisville

Follow this and additional works at: https://ir.library.louisville.edu/etd

Part of the American Politics Commons

\section{Recommended Citation}

Orr, Kevin C., "The rise of the nones: religion, leaners, and their connection with partisanship in America." (2021). Electronic Theses and Dissertations. Paper 3655.

https://doi.org/10.18297/etd/3655

This Master's Thesis is brought to you for free and open access by ThinkIR: The University of Louisville's Institutional Repository. It has been accepted for inclusion in Electronic Theses and Dissertations by an authorized administrator of ThinkIR: The University of Louisville's Institutional Repository. This title appears here courtesy of the author, who has retained all other copyrights. For more information, please contact thinkir@louisville.edu. 
THE RISE OF THE NONES:

\title{
RELIGION, LEANERS, AND THEIR CONNECTION
}

WITH PARTISANSHIP IN AMERICA

\author{
By \\ Kevin C. Orr \\ B.A., Allegheny College, 2017 \\ M.A., University of Louisville, 2021 \\ A Thesis Submitted to the Faculty of the \\ College of Arts and Sciences of the University of Louisville \\ in Partial Fulfillment of the Requirements \\ for the Degree of \\ Master of Arts in Political Science \\ Department of Political Science \\ University of Louisville \\ Louisville, Kentucky
}

May 2021 
Copyright 2021 by Kevin Connelly Orr

All Rights Reserved 

THE RISE OF THE NONES:

\title{
RELIGION, LEANERS, AND THEIR CONNECTION WITH PARTISANSHIP IN AMERICA
}

\author{
By \\ Kevin Connelly Orr \\ B.A. Allegheny College, 2017 \\ M.A. University of Louisville, 2021
}

A Thesis Approved On

April 29, 2021

by the following Thesis Committee:

Dr. Jason Gainous

Dr. David Buckley

Dr. Kathryn Kleinkopf 


\section{ACKNOWLEDGEMENTS}

I would like to thank my family, friends, and classmates for their support in helping me through these past two years. I would like to thank Lieutenant Colonel Dargavell, Master Sergeant Walsh, and the various Cadre at the University of Louisville Cardinal Battalion for their support and encouragement. I would also like to thank Dr. Gainous, Dr. Buckley, and Dr. Kleinkopf for their time, patience, and encouragement. 


\section{ABSTRACT \\ THE RISE OF THE NONES: \\ RELIGION, LEANERS, AND THEIR CONNECTION \\ WITH PARTISANSHIP IN AMERICA}

Kevin C. Orr

April 29, 2021

This thesis is based on the rise of the so-called "nones" in America - those who do not identify as religious - which has been a rapidly increasingly subgroup in the country. Along with the increase of the nones, religious belief and religious behavior have also been decreasing, showing a larger trend across the nation of a society detaching from religion. Nonetheless, religion in politics is still very visible. Additionally, another subgroup of America, the "leaners" - those who identify as Independents who lean towards Democrat or Republican - are a similar type of group to the nones in their unwillingness to identify with established groups in America. Thus, this thesis examines these two groups in two different ways- first, if nones have a higher chance of identifying as leaners, and if nones and leaners have a higher chance of not participating in civic engagement, which would show a general malaise towards American political culture.

This thesis is divided into four chapters. The first chapter is a literature review divided into sections based on the various groups and phenomena occurring in America. The second chapter in the thesis is an examination of the datasets, basic metrics of the 
variables, and metrics of religiosity and religious behavior. The third chapter is a summation of the observational studies, which used regression and cross-tabulation, with tables and graphics of the relationships between the variables. The fourth chapter is a summarization of the results, explanation of methods, and topics for future research, especially for the nones and the leaners in different ethnic groups and religions 
TABLE OF CONTENTS

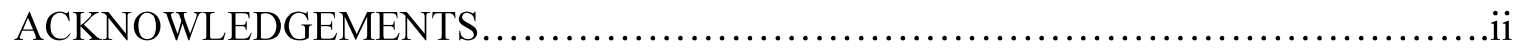

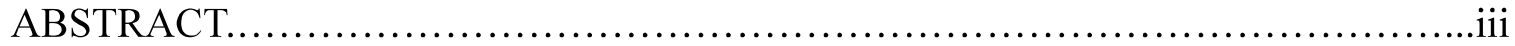

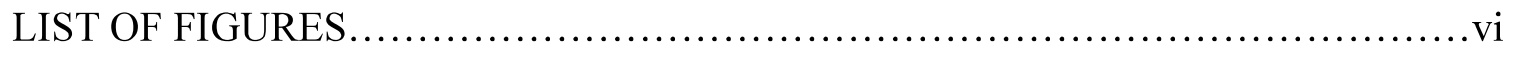

CHAPTER I: INTRODUCTION.....................................................

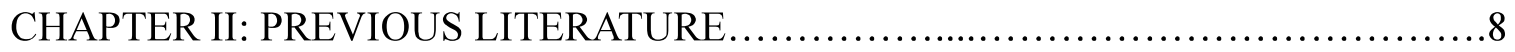

CHAPTER III: METHOD OF ANALYSIS.......................................20

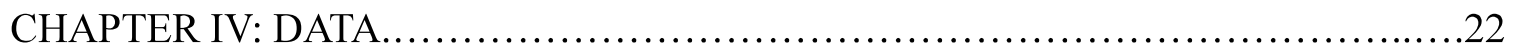

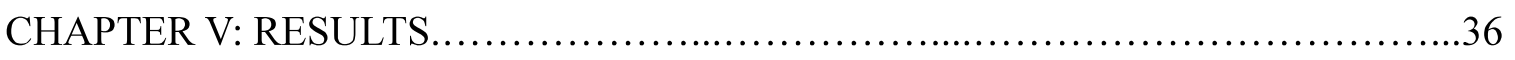

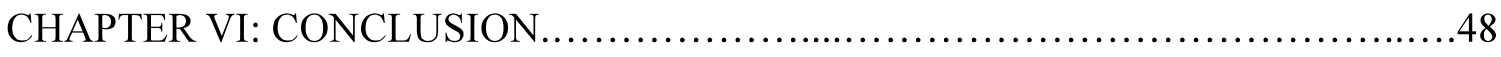

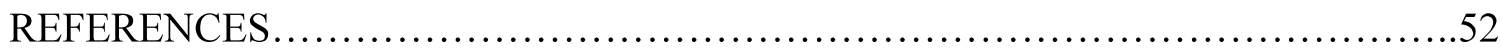

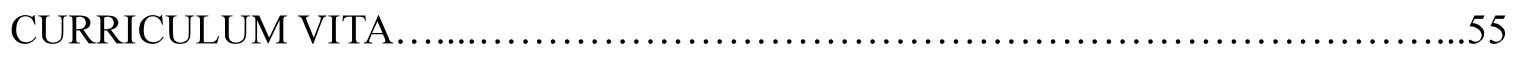




\section{LIST OF FIGURES}

\section{FIGURE}

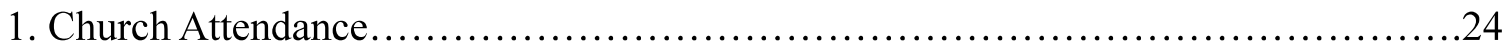

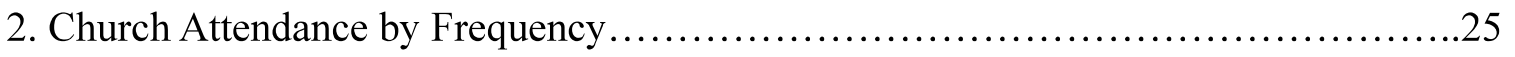

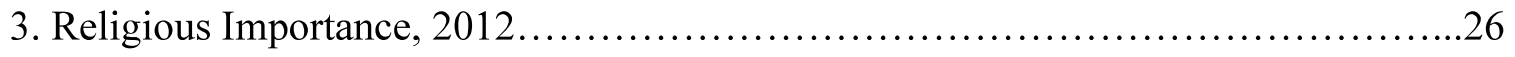

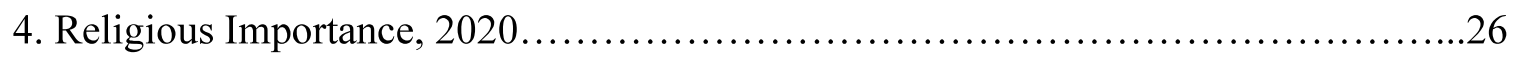

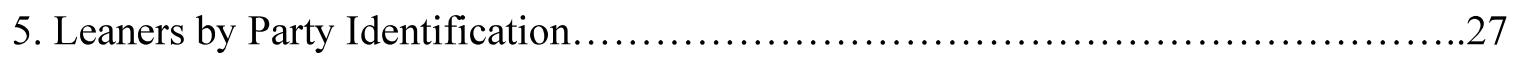

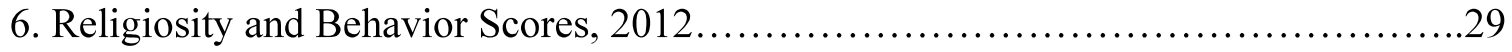

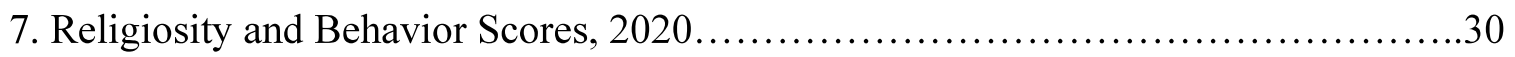

8. Nones, 7-point Political Ideology Scale.........................................32

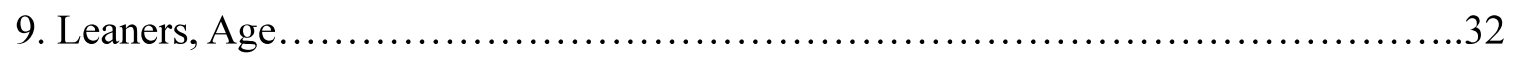

10. Leaners, 7-Point Political Ideology Scale....................................... 32

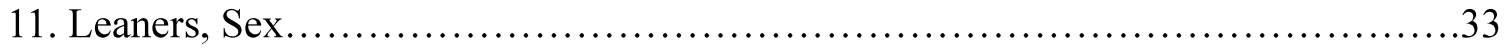

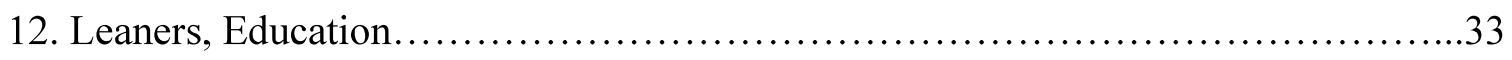

13. Religiosity and Behavior Scores, Leaners........................................3

14. Folded 7-Point Ideology Cross Tabulation, Nones and Leaners 2012 _...............37

15. Folded 7-Point Ideology Cross Tabulation, Nones and Leaners 2020 ...............37

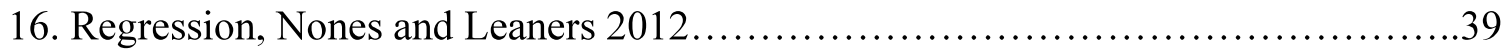

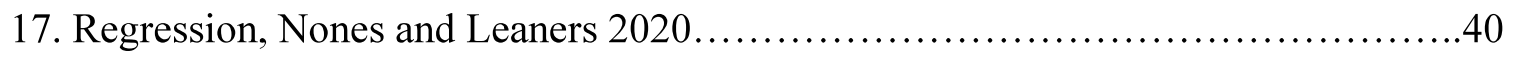

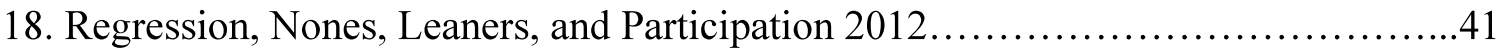




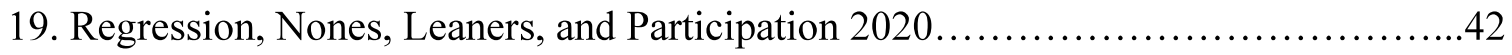

20. Interaction Plots, Nones, Leaners, and Participation.............................44

21. Nones, Age.........................................................45

22. Nones, Education..................................................... 45

23. Nones, Income................................................. 45

24. Nones, Sex................................................................ 


\section{CHAPTER I}

\section{RISE OF THE NONES IN AMERICA}

In a 2016 interview with then current President Obama, Bill Maher brought up the point that the "nones"- those Americans who select atheist, agnostic, none, no religion, etc. for their religion- would be the largest minority in America, and that the nones have no representation in Congress. Maher also mentioned that they (Maher is a proud atheist) feel like "untouchables" in the sense that they are not included in the "basket of diversity" of America. Maher certainly may have been exaggerating here, as we will see below that more and more Americans are not concerned about their candidate's religious beliefs. Nonetheless, in response, President Obama said that he would question whether or not there is any active persecution of atheists in the United States, noting that Maher himself had done very well with his tv show, and that most Americans likely do not care about something like their coworkers' religious beliefs. President Obama also stated that he would hope we create a society where all religious views, including those who do not have any, are respected. President Obama brought up an interesting point, which is that despite not having official representation in Congress, there does not appear to be active persecution of nones in the United States, and appears to rebuff Maher's contention that nones are untouchables and believes Americans don't care. However, while the

President's point may be true, a larger question may be: If Americans generally don't care 
about what religion the person sitting in the cubicle next to them practices, why does religion seem to dominate the political theater, and as Maher stated, no outed nones are in Congress?

In the United States, the rapid increase of those who identify themselves as atheists, agnostics, and "nones" - those who do not identify with any particular religion, has been rapidly increasing in the modern era. The Pew Research Center's annual surveys note two statistics in the decrease of American's affinity for religion. First, the percentage of respondents who responded that they identify as "Christian" decreased from 77 percent in 2009 to 65 percent in 2019, and second, the percentage of respondents who identify as religiously unaffiliated rose from 17 percent to 26 percent in the same time period, making the nones bigger than any racial or ethnic minority in America (Pew Research 2019). While there are many hypotheses as to what is causing Americans to "become less religious", in a previous project, I wanted to explore one of the possible variables that isn't often covered in the conversation around the topic: higher education. So, my exploration in the topic led to a central question about religion and education level to explore any possible connection.

Expanding on that, what are some of the reasons that the nones continue to become a significant portion of the American population? Especially among the future generations in America, who show far higher rates of non-religious identification than older citizens. What does that spell for the future of American politics? Are the nones concerned about their representative's religious beliefs, or even care if they act on their 
beliefs when enacting policy? Or do they simply consider their none identity as a personal matter, not worrying about that portion of those who represent them? The nones are certainly just as significant as any other growing minority group in the United States in terms of their implications on the future of the nation.

Another group in America, the so-called "leaners"- those who identify politically as "lean Democrat" or "lean Republican", are a unique cohort in the political landscape of America. The leaners place themselves on the seven-point scale of self-political identification from "strong Democrat/Republican" to "Independent" in the middle, being on either side of Independent. One would think that the leaners are essentially Independents with some views that fall within a party's platform, but research shows that is not necessarily the case.

There could be a possible connection between the nones and the leaners because of the high involvement of religion in politics, and if nones' and leaners' unwillingness to self-identify into defined groups extends to an unwillingness to be civically engaged, such as in local politics or national political campaigns. The use of religion in politics, as will be discussed below, is at an all time high. Not just in the Republican Party, notably, as Democrats are also high on religious rhetoric as well as having their main party leadership identify publicly as strong individuals of faith. Hopefully, I will learn more about how Americans in the modern age are interpreting religion in terms of how they factor it into their political decision making, both on an ideological and engagement level. Membership in religious organizations has dropped sharply, but religion still plays a large part in our politics on both sides of the aisle. So if people have declined in their 
active participation in religion, does religion, in our case Christianity, still play a large part in the minds of American voters?

One of my main contentions that is causing the rise of the nones in America is that the increased intertwinement of religion and politics is turning people off from organized religion, partisan politics, or both. So first, I wanted to look into religiosity and religious behavior on a small scale to look to see if there are differences in different subgroups, and over time. Next, I examined how likely nones are to be leaners, or in other words, if they show weak signs of partisanship on top of self-identifying as non-religious. With those two observational studies, I then wanted to examine the possibility of the fear of identification or association that nones and leaners may have in common, in the civic engagement of those in the established camps of both politics and religion may turn them off and cause them to disassociate with self-identification, and in turn, political activity, in order to not be associated with political parties. For this study, I am observing White Americans who are only either Christian or nones.

As a result, my theory is that when asked about party ID, those white Americans who are inclined to self-identify in politics as an independent, or as a "leaner", leaning towards Democrat or Republican are more likely to identify as nones, i.e "other", "none in particular", etc., or whatever answer that does not attach them to a particular religion (another survey question response could have been "spiritual but not religious").This does not rule out established Christians as discussed above from being leaners, but I contend that those who are leaners are more likely to be nones, as emphasized in $H 1$ : 
H1: White Americans who are nones are more likely to self-identify as politically moderate or "leaners", and are less likely to participate in civic engagement activities.

This paper will be exploring some political demographics among the white population of the United States who identify themselves as a Christian (Mainline Protestant, Evangelical Protestant, Catholic, Undifferentiated Christian), or self-identify as "Not Religious". While there are certainly merits to exploring and then comparing other races and religions, this project will focus on white Christians in America. The forefront of the religious activity in politics today and in the past decades has undoubtedly been the religious right, the majority of whom are white, and I wanted to get a grasp on this subgroup at first to see how they break down as they appear to be the driving force of religion in politics, especially on the right. On that note, any references hereafter, unless specified otherwise, to "religion", "religiosity", "religious behavior", etc. are in reference to Christianity, not to religion as a whole in the United States.

As the demographics of the nation continue to change, it will be interesting to see how the nones come into politics, if at all, as a rising portion of the electorate. Will there be a strong political coalition of non-believers, in groups like the Secular Coalition of America, that becomes a strong force that desires religion to be removed, or at least limited, from the political arena? Or is there a common trend through nones and leaners with their unwillingness to attach themselves to established camps in religion and politics, which could negatively affect their desire to engage in politics. It is hard to tell right now where the future of the nones as a political force is going, but if they continue 
to be a larger and larger portion of the electorate that are not strong partisans, it certainly will have implications for the future of politics as we know it in America.

\section{Results}

To begin conducting my observational study, I used results from both 2012 and 2020, given that there are different options for each dataset for nones to select from. In the 2012 study, only "No Religion" is available, and thus I only observed the results from that response, but in 2020, there are the options "Atheist", "Agnostic", or "Nothing in Particular", so I looked at each of those individually to see how the results differed, if at all.

In 2012, those respondents who selected "No Religion" are almost twice as likely to identify as a Democratic leaner than almost all other groups, and more likely to identify as a true independent, but not more likely to identify as a Republican leaner. In 2020, Atheists and Agnostics are also twice as likely to identify as a Democratic leaner than every group except for those who selected "No Religion in Particular".

Additionally, the linear regression models show a slightly positive correlation between leaners and nones in both 2012 and 2020, showing nones are slightly more likely to be leaners. While not incredibly significant, compared to the control variables of age, sex, ideology, income, and education, the coefficient for leaners is far larger than any other coefficient, and in a few cases, the coefficients for the control variables show a negative correlation. Also, the p-value for the leaners is smaller than any other control 
variable, although almost all of them achieved statistical significance with $p$ values $<0.05$.

The civic engagement models showed that there was a slightly negative correlation between leaners and nones with their political engagement in 2012. In other words, leaners and nones are more likely to have lower levels of political engagement than other white Americans. However, while leaners maintained their slight negative correlation in 2020, nones showed a positive correlation for political engagement. It would be fair to assume that because nones generally have a liberal and Democrat-leaning preference, that they may have been responding to the Trump administration and the Republican party's pious-heavy platform and legislation over the past four years. Overall, the observational study showed that while slight, there is a correlation between the leaners and the nones that makes one more likely to be a none when they are also a leaner, as well as it partially supported that the leaners and the nones are less civically engaged, except for the nones in 2020 who showed a positive correlation for civic engagement. 


\section{CHAPTER II}

\section{PREVIOUS LITERATURE ON THE TOPIC}

For the review of the previous literature on the topic, I'll break down the literature into four sections: Nones, Christianity in Politics, Leaners, and Civic Engagement. Hopefully, this will provide an accurate blueprint to help understand the rest of the project and how it came to be.

I accepted my previous project as a small, limited, and two-dimensional exploration into one possible explanation for the rise of nones in America, but still had interest in the nones. Instead, I figure that I would look more directly into the political climate of America to see if there was a connection with partisanship and religiosity, behavior, and identification. However, I continued to see polls from Gallup and Pew Research, experts brought onto prominent news shows to discuss nones, all of which certainly kept me interested in the topic. As the increase of the nones in the American society continues to gain interest, concern, and a myriad of other feelings depending on what angle one is viewing the phenomenon from, I expect more and more literature to come out about them. 


\section{i. Nones}

For this section, I'll be reviewing my independent variable, the nones. Hout and Fischer (2002) were early observers of the phenomenon of the nones in America, as their research noticed that the first real uptick of the nones in America occurred in the 1990's, and started growing at a rapid pace. They proposed three theories for the reasons for the rapid increase: demographics changes, secularization, and politics. On the politics front, they note that there could likely be an unwillingness for religious identification, "where, to declare oneself religious is to take a political stance". For instance, their conclusion from the examination of the political beliefs of the nones did show a significant correlation for moderates and liberals, likely showing that the religiousness in conservative caused moderates and liberals to select no religion in order to not be associated with religious affiliation. But interestingly enough, they proposed that there should be a decline in religious beliefs and practices among the population if there is an increase in nones, but they found none in their study. Their study was certainly at the dawn of the nones, and was not quite reflective of the nones of the modern era as the respondents in their study still were adamant in their belief in God, more like those who might identify as "spiritual but not religious" as they say in their piece. In 2014, they published a similar study, and correctly noted that their 2002 piece expected the nones to continue rising in America (Hout and Fischer 2014). The nones did continue to rise, and additionally, they found a 28 point gap in political liberals and political conservatives. Of 
those who identify as nones, 36 percent of political liberals but only 8 percent of political conservatives do not have a religious identity. They noted:

"Once the American public began connecting organized religion to the conservative political agenda - a connection that Republican politicians, abortion activists, and religious leaders all encouraged - many political liberals and moderates who seldom or never attended services quit expressing a religious preference when survey interviewers asked about it."

Hout and Fischer certainly explored a broad range of causations that would lean to the rapid increase in nones in America, and politics, especially in their studies, appears to be the main cause of "political backlash". Campbell, Green, Layman, and Sumaktoyo (2018) agree, and in their piece "Putting Politics First: The Impact of Politics on American Religious and Secular Orientations" they hypothesize that the association of religion with the GOP should make Democrats and liberals more likely to be nones. When testing that hypothesis using a fictional congressional race, they found that the introduction of highly religious rhetoric and imagery for a candidate had a large effect on Democrats, but little to none on Republicans, showing that the religious affiliation of Democrats can be malleable based on the stimuli of their environment. The study certainly showed that the religiousness of Republican politics could directly be causing the rise of the nones, especially when it comes to those on the left. So, it may just be that nones may hold objectively Christian beliefs or virtues, but do not like to identify with Christianity in America, and most definitely do not want to identify with Christian politics. Would this make them less inclined to be civically engaged if politics, at least on the right, is focused on religion? Or does it have the opposite effect and make them 
active, engaged antagonists to the Christian right? These are some of the questions I hope to answer.

The literature on the phenomenon of American nones over the past few decades certainly notes that their rise is rapid, but not many pieces know exactly where to go with that information. There seems to especially be a growing distinction being made among the different subgroups of the nones, as we'll see in the 2020 ANES survey, that those who answer "Atheist" or "Agnostic" are different citizens in terms of their beliefs than those who simply answer "Nothing in Particular" or "No Religion". The latter may just be considering themselves as "recovering Christians" who were obligated by family or social pressure to participate in religious activity, and while they may no longer actively participate, could still hold Christian views. However, atheists and agnostics could represent the rising tide of secular politics in America that the "Nothings" may or may not latch onto. The nones will certainly be interesting to follow as their visibility in America increases, and if their presence and political activity will affect the future of religion in American politics. 


\section{ii. Christianity in Politics}

Where we see to be some distinction in how white Christians and nones in America define their faith is about what parts of themselves Americans use to identify as religious, divided into religiosity and religious behavior. Examples of religious behavior could include religious activities such as just church attendance, like in Baker (2013) who used church attendance to show a negative correlation in acceptance in evolution, or could include a broader example to include how often one prays, how important religion is in one's life, religious service attendance, if religion is a guide in their life, etc. For this paper, a broader interpretation of religiosity than, that of say Baker, will be used to better understand how the population participates both personally and outside their home in being a religious human. The goal is to capture the feelings that these types of components of religiosity that is really an indicator of an individual's conscience. There is a distinction on whether an individual "attends church" or "considers themselves a member of a church", as lots of the group of Americans referred to as "Chreasters"- those who only attend church services twice a year, on Christmas and Easter, also may do so out of reliving fond childhood memories instead of devout belief (Dionne Jr. 2018). Instead, those who consider themselves a member of a church is less of a religiosity factor as it is more of an external activity (i.e. when someone is watching).

The rise of the "Christian Right" in the United States during the Reagan era in the 1980's has been primarily and almost exclusively fueled by white Americans, namely Evangelical Christians. Not to say there would not be merit in exploring communities of 
color, or of Judaism and Islam, but they most prominent religious faction in recent American politics undoubtely is composed mostly of white Christians. Once the group emerged into prominence forty years ago, religious leaders began to attempt, and eventually succeed, at mobilizing their sect as a strong voting bloc with the power to strongly influence policy in the United States (Wilcox, Jelen 1990). For example, Ted Haggard, the founder and former pastor of the New Life Church in Colorado Springs, CO used to speak with President George W. Bush or his advisors every Monday, and received an invite to speak with the President and other religious leaders in the Oval Office in late 2003 during Bush's first term. And, as noted above by Hughes, there has been a significant increase in religious rhetoric by presidents of both political parties in the last four decades (Hughes 2019). Coincidentally, the rise of the nones in America has also been rising as politics in America appears to become more intertwined with religion, as even from 2007 to 2012, the amount of "nones" rose from 15 percent to 20 percent (Pew Research 2012).

However, a large percentage of the U.S. public still believes that religion plays a positive role in society. Over $50 \%$ of U.S. adults surveyed say churches and religious organizations do more good than harm in society, strengthen morality in society, and mostly bring people together. Only approximately $20 \%$ of the respondents disagree with those notions (Pew Research 2020).

Nonetheless, Gallup noted in 2019 how there was an incredibly sharp drop in U.S. church membership over the past two decades, from above $70 \%$ from 1938 to 1998 , but as of 2018 was down to $50 \%$, and on a sharply declining trend. Additionally, among those 
with a religious preference by age, millennials show a far smaller proportion of church attendance than the other generations, but it is not necessarily just because they are younger. In 1998-2000, 68\% of Generation X respondents were church members when they were roughly the same age as today's millennials (Jones 2019).

In modern American history, the involvement of religion in politics, specifically political rhetoric, has been increasingly exponentially. When looking at Ronald Reagan, George H.W. Bush, Bill Clinton, and George W. Bush compared to their predecessors from 1933 to 1980, we've seen a more than $100 \%$ increase in presidential invocations of God, a more than $150 \%$ in religion-themed presidential proclamations, and a more than $200 \%$ increase in presidential speeches delivered at religious sites or to religious audiences (Coe, Domke 2010). Religious rhetoric in political theater may depend on who is listening however, as religion differs for everyone. Some have a more intrinsic view of religion, as it is a personal spiritual journey for them, with high aspects of religiosity involved in their faith. Some have a more extrinsic view, where fellowship and community help define their faith. Others may have a quest for answers, and be more inquisitive for faith to answer their larger questions (Jennings 2016). Jennings applied an experiment across the political spectrum, and found that firstly, those who had high extrinsic motivation were not affected by a political candidate who used more religious rhetoric than one who didn't. Those motivated by intrinsic motivation responded higher to religious rhetoric in political speech, and Jennings notes that as they view religion as a self-defining aspect of life, they likely have a sense of solidarity with politicians who speak their language, a fairly logical explanation. However, those who have "quest 
motivation" were highly dismayed by a candidate's religious rhetoric. Those who have larger questions about their faith and look for absolute truth in religion may, as Jennings puts, think that the candidates have a more dogmatic view of religion/think they are placing religion where it shouldn't be. Perhaps this is where we see the leaners fall into the most: that they do not appreciate the rhetoric as they think it is inappropriate, or they think the individual is too dogmatic.

During the Trump campaign and administration, the trend of religious rhetoric continued to an extreme extent. In an examination of political speeches from FDR to Donald Trump, Trump averaged almost double as many "religious" words in speeches compared to any other president. Even though in general, Republicans used the words at a higher rate than Democrats, Barack Obama and Ronald Regan both averaged about 4.1 religious words per 1000 words every speech (Hughes 2019). Compared with John F. Kennedy, who only averaged 1.6 religious words per 1000 words. 


\section{iii. Leaners}

Religion, while important in politics, may simply be a tangent of a candidate's platform that nones are willing to tolerate for the sake of the rest of the platform. This may explain one of the striking things about leaners, which is that one would think that they are most like independents, but that is not the case. In fact, those who identify as leaners after saying they are independents actually vote more partisan than those who identify as "weak Democrat" or "weak Republican", such as in the average of voting for Democratic presidential candidates from 1980-1992, where leaners outvoted weak Democrats $71 \%$ to $67 \%$, respectively, and both Republican and Democratic leaners were far more politically active than independents, who were much closer to weak identifiers (Smith, Tuchfarber, Rademacher, Bennett 1995). Not just in presidential races, by the way, on prominent American political issues, such as abortion, health care, the economy, etc., leaners consistently poll within small margins of the strong party identifiers, and are truly policy partisans (Magleby 2012). Thus, there is a factor that is causing these leaners to not want to self-identify with their preferred party despite holding all the same views.

Oftentimes, we hear in politics about the independents of America being the key to the election, but it appears that those who identify in the middle are far from being moderate. When asked about hot-button political issues, independents are well-distributed political spectrum in their answers despite describing themselves as moderate (Drtuman 2019). This could just simply be a response to increased partisanship in America and not wanting to be lumped together with all of the negative associations 
that come with each party, but it's an important distinction to make on how one identifies themselves versus how they think on political issues or how they vote. Are they really reluctant to vote for partisan candidates or do they just not want the association? If the latter is true, they may be less inclined to be civically engaged in politics but still make up a solid portion of the electorate for a party.

Some research has noted that labeling oneself as an "Independent" is almost more of a social response and decision than an accurate description of their political beliefs and behavior. Possibly, it may be an attempt to indicate they rise above the pettiness and ugliness of partisan American politics (Krupinov, Klar 2014). Why could that be? Self-identifying members of the population vote and act just like party identifiers and not like independents. Is it just increased partisanship that has been polarizing our population? That is likely more the symptom, and there are certainly factors that are contributing to how leaners are behaving. There is, as aforementioned, certainly literature about the phenomenon of leaners in the United States. Leaners are an incredibly interesting group that do not, at least according to the studies above, truly just "lean" one way when push comes to shove. So what causes leaners to be afraid to self-identify with a single party when asked? Certainly, one explanation could just be overall disinterest or disgust with the two-party system that has become increasingly partisan in recent history. So we will see if that trend continues as America remains highly partisan. 


\section{iv. Civic Engagement}

There certainly could be arguments made for the rise of the nones being a symptom of the decline of the social capital theory, which consists of moral obligations and norms, social values, and social networks, claiming that many of the "social problems" in America come from a decline of social capital (Putnam 1993). If fewer and fewer Americans are going to church for whatever reason, naturally they may feel less of a sense of community or belonging. Thus, as politics has become more religious, it could be driving citizens away from civic engagement, as the two used to not be intertwined. However, Frost and Edgell (2017) note that the situation is far more complex than once assumed by Putnam, at least in the non-religious community. They come as close to answering the core questions of my study as any literature that I have seen so far. They note that in previous studies on civic engagement, respondents have simply been divided into religious and non-religious participants. Instead, they take the non-religious group and divide them into more specific subgroups. They find that the aggregate group of nones, non-believers, and those who do not attend church all show lower levels of interest in politics and community affairs than religious respondents, but atheists and agnostics show just as high, if not higher, levels of interest than religious respondents. I think this is more of what was discussed earlier, that those who are firm believers in their absence of religious affiliation can be motivated to be an opposition force to the Religious Right, whereas maybe some of those who are simply indifferent to organized religion but not committed atheists or agnostics, per say, simply become less engaged overall. They also 
note that there is a growing number of political and community groups committed to nones, which they refer to as "non-religious values based communities". As discussed earlier, this could be a rising tide of a political movement of engaged nones, probably composed mostly of atheists and agnostics, possibly secularists, as a force in American politics.

Overall, there did not seem to be any existing literature about the possible connection between the nones and the leaners, or their civic engagement, likely because the nones are still a relatively new phenomenon in America that requires further and deeper study. The research on their civic engagement provided an excellent view into the future of how the nones will be viewed, as subgroups based on how fervent their non-religious attitudes and behavior are. That may open up new avenues of approach for research on the leaners and their connections to the nones, to see if "nothing" leaners are the same as atheist and agnostic leaners. However, there certainly seemed to be the connection in the unwillingness to self-identify into a large group of American society, whether that be an established religion or political party. I thought that after establishing basic scores of religiosity and behavior, I could explore how the religious subgroups identify politically, and see if nones are more likely to self-identify as leaners compared to respondents from other religious groups. 


\section{CHAPTER III \\ METHOD OF ANALYSIS}

As aforementioned, I will first establish baseline measures of religiosity and behavior for religious subgroups to examine any differences in scores among groups and over time. These scores will to see which subgroups show what level of scores between the two measures, and to see if nones are truly not religious, or if they are just identifying as such. That way, the further studies into nones have verified that they show both low scores in religiosity and behavior. Secondly, I will examine if leaners are more likely to be nones by using the ANES data sets from the years 2012 and 2020, using the time periods to also track the change over time. While I don't expect to see monumental change, the eight-year period in question contained is marked by lots of political tumultuousness with the second term of Barack Obama, the election of Donald Trump and his first presidential term, the COVID-19 pandemic, and even religious crises like the Catholic sex abuse scandal continued to rage on. It is a short period of time, but it should be enough to track trends in what I am attempting to uncover.

I'll be using $\mathrm{R}$ to perform this data analysis. I'll be first showing the demographics of the leaners, and then the demographics of the nones. Following the establishment of that basic information, I'll go ahead and examine the religiosity and 
religious behavior scores for each of the subgroups of Christians and nones. Then, I'll show the cross tabulations and regression models. With $\mathrm{R}$, the graphics are a valuable tool to illustrate the data and support my conclusions. If I were to just use qualitative sources, I don't think it would be able to convey the same contentions as using statistical analysis and graphics for a study that is examining religion based from several different angles. Overall, I think the outputs from $\mathrm{R}$ will be substantial enough to track general trends and give me a good idea about the validity behind some of my contentions. 


\section{CHAPTER IV}

\section{DATA}

To begin, I use some baseline statistics of my independent and dependent variables over the time period 2012 to 2020 to show that American's overall Christian behavior and mindset are all trending away from religiosity and religious behavior. Once again, my metrics that show religiosity and religious behavior- if religion is an important part in a respondent's life; if one attends church outside of regular baptisms, weddings, funerals, etc.; and how often the church going population attends church (divided into answers ranging from weekly to never). On top of the phenomenon of the nones, these trends are not exactly something groundbreaking, as institutions such as Pew Research and Gallup have been tracking these for decades. For example, Gallup's 2020 results show that for the first time in their history, the percentage of the population who belong to a church, synagogue, mosque, etc. has dropped below 50 percent, to 47 percent (Jones 2021).

To start, we'll look at some basic metrics run through the ANES data set that show how the changes in some of our metrics over the time period from 2012 to 2020. First, we'll look at the survey question: 
"Lots of things come up that keep people from attending religious services even if they want to. Thinking about your life these days, do you ever attend religious services, apart from occasional weddings, baptisms or funerals? 


\section{Figure 1}

\begin{tabular}{|c|c|c|}
\hline $\begin{array}{c}\text { Regular Church } \\
\text { Attendance (outside of } \\
\text { baptisms, funerals, } \\
\text { weddings, etc.) }\end{array}$ & Yes & No \\
\hline 2012 & $59.9 \%$ & $39.6 \%$ \\
\hline 2020 & $48.2 \%$ & $50.9 \%$ \\
\hline
\end{tabular}

The wording on this question is rather interesting. It frames church attendance as the thing that often has to give when people become too busy in life, and almost gives them an "out" in the question for why they don't attend church often. However, the framing is apt here in order to truly gauge a respondent's church attendance. As we can see from the table, the difference of about 11 percentage points in each response in the direction of lower regular church attendance is quite a significant change. It does follow the annual trends we see in polls such as from Pew Research and Gallup, but it does show how stark the change in American religious culture has been in just the past eight years.

To go further on the question of church attendance, the ANES series asks a follow-up question for those who answered "Yes" to the question about regular church attendance:

"Do you go to religious services [every week, almost every week, once or twice a month, a few times a year, or never/ never, a few times a year, once or twice a month, almost every week, or every week]?” 
Figure 2

\begin{tabular}{|c|c|c|c|c|c|c|}
\hline $\begin{array}{l}\text { Church } \\
\text { How } \\
\text { Often }\end{array}$ & Weekly & Almost Weekly & $\begin{array}{l}\text { Once/twice } \\
\text { per month }\end{array}$ & $\begin{array}{l}\text { Few times } \\
\text { a year }\end{array}$ & Never & $\begin{array}{l}\text { Percent of } \\
\text { Respondents } \\
\text { Applicable }\end{array}$ \\
\hline 2012 & $37.2 \%$ & $19.6 \%$ & $17.4 \%$ & $24.8 \%$ & $0.84 \%$ & $59.9 \%$ \\
\hline 2020 & $31.3 \%$ & $23.1 \%$ & $16.5 \%$ & $26.5 \%$ & $2.7 \%$ & $48.2 \%$ \\
\hline
\end{tabular}

Even among the respondents who self-identify as regular church-goers, there is still a significant decline of 6 percentage points in the past eight years, whereas the other answers are a sort of mixed bag, with interesting trends. For example, the amount of respondents who chose "Almost Weekly", and "A Few Times a Year" saw an increase. Even though the statistics show an increase, what it could really show is a negative trending general shift in how often people say they attend church services, indicative of a decline in religiosity and behavior.

The third metric, religious importance, is slightly difficult to compare over the time period we are examining as the answer options for the respondents have changed from 2012 to 2020 . Although the question has stayed close to the same, "Now on another topic.... Do you consider religion to be an IMPORTANT part of your life, or NOT?" (2012) compared to "Now on another topic: How important is religion in your life?" (2020). The difference being that in 2012, the only answers were: (1) Important and (2) Not Important. However, in 2020, there was a five-point scale for respondents to choose from, starting with (1) Extremely Important, (2) Very Important, (3) Moderately 
Important, (4) A Little Important, and (5) Not Important At All. This creates a bit of an issue to compare the two results side to side.

Figure 3

\begin{tabular}{|l|l|l|}
\hline Religion Important? & Yes & No \\
\hline 2012 & $69.3 \%$ & $30.0 \%$ \\
\hline
\end{tabular}

In just over a 2:1 margin, the respondents in 2012 indicated that religion was an important part of life. In 2020, the question featured the five-point scale which gave the respondents a much better choice of answers on how important religion is in their lives.

Figure 4

\begin{tabular}{|l|l|l|l|l|l|}
\hline $\begin{array}{l}\text { Religion } \\
\text { Important? }\end{array}$ & Extremely & Very & Moderately & A Little & Not at All \\
\hline 2020 & $27.5 \%$ & $19.1 \%$ & $19.2 \%$ & $12.9 \%$ & $20.8 \%$ \\
\hline
\end{tabular}

As we can see in the above table, the percentage of the respondents who indicate that religion is an extremely, very, or at least moderately important part of their life comprises of about 66 percent of the population, and those who believe religion to be a little or not at all important comes in at about 34 percent. While it would be difficult to gauge how the respondents in the 2012 survey would have responded on the five point scale, taking the first three responses of the 2020 survey and comparing them to "Yes" for the 2012 
survey, and the last two from the 2020 survey and comparing them to "No" seems the best way to gauge how people have been slowly believing religion is a less important part of their lives.

Now that we've established some very basic statistics about the dataset's religious metrics, we can move on to showing some statistics about the leaners and the nones. For the leaners, the dataset relies on a follow-up question to the party identification question for those who self-identify as an independent. For those who answered "Independent", the question is: "Do you think of yourself as CLOSER to the Republican Party or to the Democratic party?" the respondent can choose to be closer to either party, or remain as an independent. The variables are coded as "1" as closer to Democrat, " 2 " as Independent, and " 3 " as closer to Republican. We can see in 2012 , that the trend was generally (although not overwhelmingly) trending towards the Democrat side, with many holding firm that they are independents. The same thing can be seen in 2020 , with a slight deviation back to where the results are almost all within a percentage point of each other. These charts show that approximately one-third of the respondents are identifying as independents, and subsequently about two out of three self-identified Independents lean towards a party when pushed. Here are leaners broken down by percentage:

\section{Figure 5}

\begin{tabular}{|c|c|c|c|c|}
\hline Leaners & Lean GOP & Independent & Lean Dem & $\begin{array}{c}\text { Total } \\
\text { Percentage of } \\
\text { Respondents }\end{array}$ \\
\hline 2012 & $10.3 \%$ & $12.1 \%$ & $12.6 \%$ & $\sim 35.0 \%$ \\
\hline 2020 & $10.6 \%$ & $11.6 \%$ & $11.7 \%$ & $\sim 33.9 \%$ \\
\hline
\end{tabular}


As we can see in the hard numbers, there really has not been too much of a change in the numbers of Independents, or even in the deviation during the time period of 2012 to 2020, except maybe almost an entire percentage point decline in those who lean Democrat. Thus, true "leaners" likely make up about 22 to 25 percent of the US population.

Our independent variable, the "nones", are a little harder to capture in the two surveys. In 2012, the options that do not include a faith in the answer are either "Other Religion" or "Not Religious". In the 2020 survey, the answers are far broader and provide the respondent with many more options, such as "Atheist", "Agnostic", "Something Else" or "Nothing in Particular". The difference in the "Other Religion" choice in 2012 compared to the "Something Else" removes the "religion" part, and allows people who may not be religious (spiritual, too embarrassed to identify as religious, etc.) to have a less defining option.

The next step is to break down the religiosity and religious behavior scores for all of the subgroups by combining the means of the variables to give each group their score. For religiosity, the score will be ranging from 1, being the highest amount of religiosity, to 5, being the lowest amount. For religious behavior, the score is out of 7, with 1 being the highest amount of religious behavior, and 7 being the lowest amount of religious behavior. This is the sum of the max range for general church attendance (2) and the frequency of church attendance (5). Since part of the hypotheses is that there is a difference in religious behavior and religiosity among white Americans, I separated these values to see if there was deviation in the groups and if there was a significant difference 
among groups like the undifferentiated Christians, Evangelical Christians, etc., and to see if the nones are more likely to be leaners in order to avoid being identified with political parties. So, below, I have the Christian groups broken down by faith and by the year with their religiosity and religious behavior scores.

\section{Figure 6}

\begin{tabular}{|l|c|c|}
\hline $\mathbf{2 0 1 2}$ & $\begin{array}{c}\text { Religiosity } \\
\text { (1 (high) -5 (low) }\end{array}$ & $\begin{array}{c}\text { Behavior } \\
\text { (1 (high)- 7 (low) })\end{array}$ \\
\hline Evangelicals & 2.53 & 3.33 \\
\hline Mainline Protestant & 3.13 & 3.63 \\
\hline Roman Catholic & 3.14 & 3.76 \\
\hline Undifferentiated Christian & 2.71 & 3.47 \\
\hline Not Religious & 4.23 & 6.89 \\
\hline Other Religion & 3.24 & 3.31 \\
\hline
\end{tabular}




\section{Figure 7}

\begin{tabular}{|l|c|c|}
\hline $\mathbf{2 0 2 0}$ & $\begin{array}{c}\text { Religiosity } \\
\text { (1 (high) -5 (low) }\end{array}$ & $\begin{array}{c}\text { Behavior } \\
\text { (1 (high)- 7 (low) })\end{array}$ \\
\hline Protestants & 2.94 & 3.45 \\
\hline Catholics & 3.36 & 3.92 \\
\hline Orthodox & 3.14 & 3.76 \\
\hline Latter Day Saints & 2.71 & 3.47 \\
\hline Atheists & 4.91 & 5.70 \\
\hline Agnostics & 4.77 & 5.48 \\
\hline Nothing in Particular & 4.18 & 5.37 \\
\hline $\begin{array}{l}\text { Nones (Atheists, Agnostics, } \\
\text { Nothing in Particular) }\end{array}$ & 4.41 & 5.42 \\
\hline
\end{tabular}

The 2012 survey has a separate identifier for Evangelicals, and rather unsurprisingly, they were the highest scoring group except for the "Other Religion" group, which scored slightly higher in the behavior category. Both the Evangelicals and the Undifferentiated Christians scored below a 3 in the religiosity category, which indicates that both groups believe that religion is a very important part of their life.

Among Christians in general, the Catholics scored the lowest on the religious behavior score, indicating that they were the group as of 2012 which were the least likely to attend church and attend it as regularly as the other groups. Additionally, their 
religiosity score was the same as the Mainline Protestants, but the Protestants had a higher score on behavior showing they were slightly more likely to participate in attending church.

The only options in the 2012 survey that was not an established religion or sect of a religion were "Not Religious" and "Other Religion". In that wording, the only answers for nones, atheists, agnostics, spiritual but not religious, etc., would be those two. While comparatively there were not a lot of respondents who chose "Other Religion" (4.27\%), the "Not Religious" selection garnered $21.25 \%$ of the respondents, on par with how the aforementioned Pew Research, Gallup, and other studies have been tracking the growth of the nones in America. From this point, I won't be including "Other Religion" into my dataset and experiments as I feel it is too broad to capture what I am looking for. For example, there is no answer for Muslims, Hindus, or Buddhists, which could very likely make up a significant proportion of the $4.2 \%$ and enough to unnecessarily taint the data.

Now we can look a little more deeply into the subgroup of the nones from 2012 and 2020 and some of their demographics, which we will use as control variables, such as age and political ideology, which asks respondents to identify themselves on a liberal-conservative scale, rather than party identification, which is on a Democrat-Republican scale.. 


\section{Figure 8}

\begin{tabular}{|l|l|l|l|l|l|l|l|}
\hline $\begin{array}{l}\text { Nones, } \\
\text { Political } \\
\text { Ideology }\end{array}$ & $\begin{array}{l}\text { Extremely } \\
\text { Liberal }\end{array}$ & Liberal & $\begin{array}{c}\text { Slightly } \\
\text { Liberal }\end{array}$ & Moderate & $\begin{array}{c}\text { Slightly } \\
\text { Conserv. }\end{array}$ & Conserv. & $\begin{array}{c}\text { Extremely } \\
\text { Conserv. }\end{array}$ \\
\hline 2012 & $4.38 \%$ & $16.07 \%$ & $13.92 \%$ & $32.37 \%$ & $8.11 \%$ & $7.80 \%$ & $2.23 \%$ \\
\hline 2020 & $8.94 \%$ & $23.38 \%$ & $14.05 \%$ & $22.55 \%$ & $7.40 \%$ & $8.10 \%$ & $0.792 \%$ \\
\hline
\end{tabular}

As $H 1$ states, the assumption is that the leaners in white America are more likely to be nones. So, let's take a closer look at the leaners and how they fit into American society.

\section{Figure 9}

\begin{tabular}{|l|l|l|l|}
\hline Leaners, Age & Mean & Median & \multicolumn{1}{|c|}{ Range } \\
\hline Leaners 2012 & 49.04 & 51.00 & $18-90$ \\
\hline Leaners 2020 & 49.58 & 49.00 & $18-80$ \\
\hline
\end{tabular}

\section{Figure 10}

\begin{tabular}{|l|l|l|l|l|l|l|l|}
\hline $\begin{array}{l}\text { Leaners, } \\
\text { Political } \\
\text { Ideology }\end{array}$ & $\begin{array}{c}\text { Extremely } \\
\text { Liberal }\end{array}$ & Liberal & $\begin{array}{c}\text { Slightly } \\
\text { Liberal }\end{array}$ & Moderate & $\begin{array}{c}\text { Slightly } \\
\text { Conserv. }\end{array}$ & Conserv. & $\begin{array}{c}\text { Extremely } \\
\text { Conserv. }\end{array}$ \\
\hline $\begin{array}{l}\text { Leaners } \\
2012\end{array}$ & $1.55 \%$ & $7.73 \%$ & $12.38 \%$ & $31.69 \%$ & $14.15 \%$ & $15.25 \%$ & $2.87 \%$ \\
\hline $\begin{array}{l}\text { Leaners } \\
2020\end{array}$ & $4.8 \%$ & $10.84 \%$ & $15.10 \%$ & $27.35 \%$ & $15.37 \%$ & $14.29 \%$ & $2.54 \%$ \\
\hline
\end{tabular}




\section{Figure 11}

\begin{tabular}{|l|c|c|}
\hline Leaners, Sex & Male & Female \\
\hline Leaners 2012 & $54.09 \%$ & $45.91 \%$ \\
\hline Leaners 2020 & $51.78 \%$ & $47.68 \%$ \\
\hline
\end{tabular}

\section{Figure 12}

\begin{tabular}{|l|c|c|c|c|c|}
\hline $\begin{array}{l}\text { Leaners, } \\
\text { Education }\end{array}$ & $\begin{array}{c}\text { Less than } \\
\text { High School } \\
(1)\end{array}$ & $\begin{array}{c}\text { High School/ } \\
\text { GED } \\
(2)\end{array}$ & $\begin{array}{c}\text { Some post- } \\
\text { High School } \\
(3)\end{array}$ & $\begin{array}{c}\text { Bachelor's } \\
\text { Degree } \\
(4)\end{array}$ & $\begin{array}{c}\text { Graduate } \\
\text { Degree } \\
(5)\end{array}$ \\
\hline $\begin{array}{l}\text { Leaners } \\
2012\end{array}$ & $9.14 \%$ & $21.74 \%$ & $34.49 \%$ & $20.34 \%$ & $13.26 \%$ \\
\hline $\begin{array}{l}\text { Leaners } \\
2020\end{array}$ & $3.83 \%$ & $13.21 \%$ & $33.06 \%$ & $26.80 \%$ & $21.95 \%$ \\
\hline
\end{tabular}

The most staggering statistic of the leaners is that their political ideology is truly not that much different from the rest of the respondents. The most deviation from the ANES set is just over three percentage points on any of the ideology options, and most of them were within 1-2 percentage points. But when the political self-identification question is asked, the leaners all identify as independents, but ideally, they would all fall into either "moderate" or the "slightly", but only approximately 57 percent of them do, while the rest fall into either identifying themselves as liberal, conservative, or even extremely liberal or extremely conservative. It certainly is an interesting statistic that the 
leaners are less hesitant to identify their ideology, but are far more closed off when being attached to a political party.

The leaners, as things considered, are relatively reflective of the population. The leaners who identify themselves as having "No Religion" is about the same as the population with about one-fifth to one-fourth of the population. The leaners who identify as Catholics is the second highest amount.

Now, as we did with all of the subgroups of religion, we're going to examine the religiosity and behavior variables for religion and give the leaners a religiosity and behavior score.

\section{Figure 13}

\begin{tabular}{|l|l|l|}
\hline $\begin{array}{l}\text { Religious Scores for } \\
\text { Leaners }\end{array}$ & Religiosity 1 (high)- 5(low) & Behavior 1 (high)- 7(low) \\
\hline Leaners 2012 & 3.39 & 3.87 \\
\hline ANES 2012, Whites & 3.19 & 3.73 \\
\hline Leaners 2020 & 3.69 & 4.13 \\
\hline ANES 2020, Whites & 3.49 & 3.98 \\
\hline
\end{tabular}

Leaners are slightly less religious, generally speaking, than the population we have selected. However, it is not a huge deviation. The leaners do however hold both a higher religiosity and behavior score than any of the religion subgroups, except for the ones who selected "No Religion", which is a bit of an outlier in the set, and understandably so. So, what do we see? That Leaners are pretty representative of the white population, maybe a 
little bit less religious, more likely to be a male, and more educated. Additionally, in the religious scores for the two time periods, we see that both the leaners and the general population follow the trend that America, overall, is becoming less religious. 


\section{CHAPTER V}

\section{RESULTS}

The first observational study on religious groups and their ideology is to see if religious self-identification can be a predicting factor in if one self-identifies as a leaner or a strong partisan identifier. The amounts in the boxes are the results from a row-conditional cross-tabulation, showing how likely each group would be to identify on the seven-point political party self-identification scale, which is "folded". I will do the same thing with ideology as my control variable in later observations. The strong identifiers, which include "Strong Democrat" or "Strong Republican" are grouped together. Then, the more moderate party identifiers "Not Very Strong Democrat/Republican" are also grouped together. Next, leaners, or "Independent-Democrat" or "Independent-Republican" are placed together under "Leaners". Finally, "Independent" is in its own category. This will help measure a respondent's overall strength of party identification. The important goal of this observational study is to compare the leaners to strong party identifiers, since we're looking for a general "unwillingness to identify" factor that would be associated with both being a none and being a leaner. 
Figure 14

\begin{tabular}{|l|c|c|c|c|}
\hline $\mathbf{2 0 1 2}$ & $\begin{array}{c}\text { Strong } \\
\text { Dem/GOP }\end{array}$ & $\begin{array}{c}\text { Not Very } \\
\text { Strong } \\
\text { Dem/GOP }\end{array}$ & Leaners & Indep. \\
\hline $\begin{array}{l}\text { Main. } \\
\text { Protest. }\end{array}$ & 38.74 & 29.34 & 22.50 & 9.40 \\
\hline $\begin{array}{l}\text { Evan. } \\
\text { Protest. }\end{array}$ & 49.72 & 23.20 & 18.45 & 8.63 \\
\hline Catholic & 37.28 & 27.21 & 22.69 & 12.84 \\
\hline $\begin{array}{l}\text { Undif. } \\
\text { Christ. }\end{array}$ & 39.58 & 23.85 & 23.97 & 12.61 \\
\hline $\begin{array}{l}\text { No } \\
\text { Religion }\end{array}$ & 27.51 & 24.64 & 28.07 & 19.78 \\
\hline
\end{tabular}

Figure 15

\begin{tabular}{|l|c|c|c|c|}
\hline 2020 & $\begin{array}{c}\text { Strong } \\
\text { Dem/GOP }\end{array}$ & $\begin{array}{c}\text { Not Very } \\
\text { Strong } \\
\text { Dem/GOP }\end{array}$ & Leaners & Indep. \\
\hline Protest. & 54.71 & 19.89 & 19.61 & 6.33 \\
\hline Catholic & 43.23 & 25.24 & 21.59 & 9.94 \\
\hline Orthodox & 39.61 & 23.38 & 24.68 & 12.34 \\
\hline Atheist & 39.71 & 17.65 & 28.52 & 14.12 \\
\hline Agnostic & 36.63 & 19.96 & 32.68 & 10.75 \\
\hline $\begin{array}{l}\text { Something } \\
\text { Else }\end{array}$ & 48.23 & 18.12 & 20.76 & 12.89 \\
\hline Nothing & 34.19 & 21.55 & 24.75 & 19.51 \\
\hline
\end{tabular}


The cross-tabulation models show that nones as a whole in 2012 , as well as atheists, agnostics, and "nothings" all show a higher chance of being leaners than any other group, especially strong partisans. Next, I ran a simple regression model with the model of nones either being leaners or strong partisans, compared to all of my control variables. For one of my control variables, ideology, I took the 7 point ideology scale and similarly "folded" the options for respondents, so that anyone who answered "Extreme Liberal/Conservative, Liberal/Conservative, Slightly Liberal/Moderate/Slightly Conservative" were combined. The results showed that there is a positive correlation between being a leaner and a none in 2012, but showing a negative correlation in 2020 . There were high negative correlations in respondents who chose "Extreme Liberal/Conservative" or "Liberal/Conservative" on the 7-point ideology scale in 2012, showing that those identifying strongly ideologically are not prone to identify as a none, which I found incredibly interesting. Two religious control variables from earlier, church attendance and religious importance, were also added. 
Figure 16

\begin{tabular}{|l|l|l|l|l|}
\hline $\mathbf{2 0 1 2}$ & Estimate & Standard Error & T-Value & P-Score \\
\hline (Coefficient) & 0.3665 & 0.0302 & 12.122 & $<2 \mathrm{e}-16$ \\
\hline Nones & 0.1147 & 0.0176 & 6.521 & $7.61 \mathrm{e}-11$ \\
\hline Church Attend. & 0.0237 & 0.0176 & 1.348 & 0.1778 \\
\hline Religion Import. & -0.0148 & 0.0141 & -1.049 & 0.2941 \\
\hline $\begin{array}{l}\text { Extreme } \\
\text { Liberal/Conserv. }\end{array}$ & -0.1737 & 0.0316 & -5.494 & $4.11 \mathrm{e}-08$ \\
\hline Liberal/Conserv. & -0.1655 & 0.0215 & -7.685 & $1.80 \mathrm{e}-14$ \\
\hline $\begin{array}{l}\text { Slight } \\
\text { Liberal/Conserv/ } \\
\text { Moderate }\end{array}$ & 0.0210 & 0.0195 & 1.076 & 0.2818 \\
\hline Age & -0.0004 & 0.0004 & -1.132 & 0.2576 \\
\hline Sex & 0.0490 & 0.0129 & 3.787 & 0.0002 \\
\hline Income & -0.0007 & 0.0009 & -0.786 & 0.4318 \\
\hline Education & 0.0079 & 0.0061 & 1.298 & 0.1943 \\
\hline
\end{tabular}




\section{Figure 17}

\begin{tabular}{|l|l|l|l|l|}
\hline $\mathbf{2 0 2 0}$ & Estimate & Standard Error & T-Value & P-Score \\
\hline (Coefficient) & 0.0801 & 0.0095 & 8.452 & $<2 \mathrm{e}-16$ \\
\hline Nones & -0.0305 & 0.0035 & -8.646 & $<2 \mathrm{e}-16$ \\
\hline Church Attend. & $\mathbf{- 0 . 0 0 0 7}$ & $\mathbf{0 . 0 0 4 5}$ & $\mathbf{- 0 . 1 4 5}$ & $\mathbf{0 . 8 8 4 6}$ \\
\hline $\begin{array}{l}\text { Religious } \\
\text { Import. }\end{array}$ & $\mathbf{- 0 . 0 0 3 2}$ & $\mathbf{0 . 0 0 5 7}$ & $\mathbf{- 0 . 5 5 4}$ & $\mathbf{0 . 5 7 9 3}$ \\
\hline $\begin{array}{l}\text { Extreme } \\
\text { Liberal/Conserv. }\end{array}$ & -0.0020 & 0.0041 & -0.494 & 6.6216 \\
\hline Liberal/Conserv. & -0.0033 & 0.0056 & -0.583 & 0.5599 \\
\hline $\begin{array}{l}\text { Slight } \\
\text { Liberal/Conserv/ } \\
\text { Moderate }\end{array}$ & -0.0026 & 0.0047 & -0.552 & 0.5811 \\
\hline Age & -0.0007 & 0.0095 & -7.080 & $1.62 \mathrm{e}-12$ \\
\hline Sex & -0.0031 & 0.0031 & -0.980 & 0.3231 \\
\hline Income & -0.0003 & 0.0003 & -1.238 & 0.2157 \\
\hline Education & -0.0027 & 0.0015 & -1.782 & 0.0748 \\
\hline
\end{tabular}

The Nones had a positive correlation in 2012, but had a negative correlation in 2020. Thus, for 2012, a none still had a higher chance to be a leaner rather than a strong partisan identifier, but in 2020, a none had a higher chance of being a strong partisan identifier. Next, I wanted to see how the nones behaved in political activity. I created an additive index of civic engagement values that included: Did you vote in the last general election, have you contacted your Representative or Senator (in the last four years for 2012 , in the last twelve months for 2020), and have you given money to a political party 
(in the last four years for 2012, in the last twelve months for 2020). The additive index for civic engagement is the dependent variable in these next two tables, and I added the leaners in as a control variable to see how the results panned out.

\section{Figure 18}

\begin{tabular}{|l|l|l|l|l|}
\hline $\mathbf{2 0 1 2}$ & Estimate & Standard Error & T-Value & P-Score \\
\hline (Coefficient) & 0.6082 & 0.0505 & 12.050 & $<2 \mathrm{e}-16$ \\
\hline Nones & -0.706 & 0.0234 & -3.018 & 0.0026 \\
\hline Leaners (Party ID) & -0.0730 & 0.0182 & -4.010 & $6.16 \mathrm{e}-05$ \\
\hline Church Attend. & -0.6243 & 0.0231 & -26.969 & $<2 \mathrm{e}-16$ \\
\hline Religion Import. & -0.8842 & 0.0186 & -47.568 & $<2 \mathrm{e}-16$ \\
\hline $\begin{array}{l}\text { Extreme } \\
\text { Liberal/Conserv. }\end{array}$ & 0.0515 & 0.0356 & 1.449 & 0.1475 \\
\hline Liberal/Conserv. & -0.1072 & 0.0224 & -4.782 & $1.79 \mathrm{e}-06$ \\
\hline $\begin{array}{l}\text { Slight } \\
\text { Liberal/Conserv/ } \\
\text { Moderate }\end{array}$ & -0.0151 & 0.2216 & -0.681 & 0.4959 \\
\hline Age & 0.0048 & 0.0011 & 4.204 & $2.67 \mathrm{e}-05$ \\
\hline Sex & 0.0563 & 0.0081 & 6.980 & $3.36 \mathrm{e}-12$ \\
\hline Income & 0.0048 & 0.0171 & 0.281 & $<2 \mathrm{e}-16$ \\
\hline Education & 0.0005 & 10.168 & 0.7789 \\
\hline
\end{tabular}


Figure 19

\begin{tabular}{|l|l|l|l|l|}
\hline $\mathbf{2 0 2 0}$ & Estimate & Standard Error & T-Value & P-Score \\
\hline (Coefficient) & -0.1902 & 0.1559 & -1.220 & 0.2224 \\
\hline Nones & 0.0696 & 0.0119 & 5.837 & $5.55 \mathrm{e}-09$ \\
\hline Leaners (Party ID) & -0.0666 & 0.1543 & -0.432 & 0.6658 \\
\hline Church Attend. & 0.2028 & 0.0143 & 14.165 & $<2 \mathrm{e}-16$ \\
\hline Religion Import. & 0.0252 & 0.0179 & 1.413 & 0.1577 \\
\hline $\begin{array}{l}\text { Extreme } \\
\text { Liberal/Conserv. }\end{array}$ & 0.0111 & 0.1541 & 0.072 & 0.9426 \\
\hline Liberal/Conserv. & -0.1023 & 0.1543 & -0.663 & 0.5073 \\
\hline $\begin{array}{l}\text { Slight } \\
\text { Liberal/Conserv/ } \\
\text { Moderate }\end{array}$ & -0.0052 & 0.0184 & 0.282 & 0.7782 \\
\hline Age & 0.0028 & 0.0003 & 8.957 & $<2 \mathrm{e}-16$ \\
\hline Sex & 0.0024 & 0.1024 & 0.238 & 0.8117 \\
\hline Income & 0.0018 & 0.0008 & 2.181 & 0.0292 \\
\hline Education & 0.0467 & 00.50 & 9.424 & $<2 \mathrm{e}-16$ \\
\hline
\end{tabular}

However, in 2020, nones are slightly more inclined to participate politically, while leaners maintained similar levels of negative correlation towards civic engagement. I think this could be attributed to the increasing levels of religious fundamentalism in politics on the right that may have energized the nones to make such a swing. 
I think this may be the beginning of what I discussed earlier about the different subgroups of the nones beginning to become politically active, and may be starting to warm up to speaking up for themselves

Finally, here are interaction plots of the civic engagement index model when I multiplied the effect of being a leaner on being a none. Once again, in 2020 it is harder to see a strong trend as the time frames for some of the civic engagement index questions are four times less than the 2012 models, but I can still draw some conclusions from the graphics.

In 2012, there is a stark decline for nones in their civic engagement (partindex) as they become more likely to be a leaner, or " 1 " instead of a strong identifier " 0 ". Additionally, the Christian population, the dashed light blue line, is in general more likely to be civically engaged than the nones who are the solid navy lines. However, in 2020, the roles reverse, and the nones are more likely to be civically engaged than the Christian population, though both the nones and the Christians still show decline in civil engagement when becoming closer to a leaner than as a strong identifier. 


\section{Figure 20}

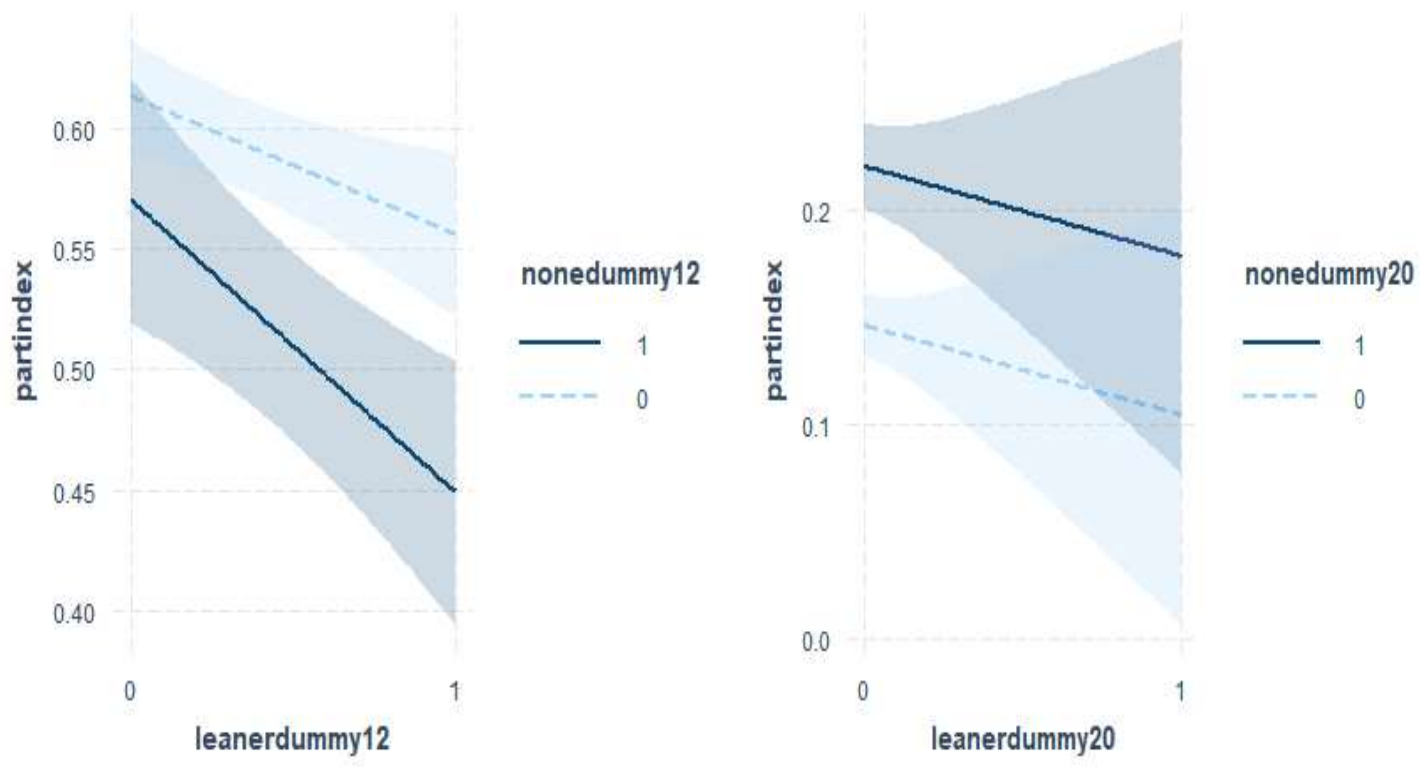

How can we interpret these figures? I think, as I talked about earlier, that the subgroups of the nones may be starting to push their civic engagement and may have been motivated by the four years of the Trump administration to do so. However, I think it will be interesting to see if they continue to be active, or if the election of Joe Biden has them "calm down" and go back to being relatively civically unengaged.

Additionally, the t-tests and cross-tabulations of the control variables are shown here. 
Figure 21

\begin{tabular}{|l|c|c|c|c|}
\hline Age, nones & T-Score & Conf. Interval & Mean & P-Value \\
\hline 2012 & 97.138 & $44.29-46.11$ & 45.20 & $2.2 \mathrm{e}-16$ \\
\hline 2020 & 129.02 & $44.95-46.33$ & 45.64 & $2.2 \mathrm{e}-16$ \\
\hline
\end{tabular}

Figure 22

\begin{tabular}{|l|c|c|c|c|}
\hline Education, nones & T-Score & Conf. Interval & Mean & P-Value \\
\hline 2012 & 88.255 & $2.89-3.02$ & 2.95 & $2.2 \mathrm{e}-16$ \\
\hline 2020 & 146.64 & $3.36-3.49$ & 3.40 & $2.2 \mathrm{e}-16$ \\
\hline
\end{tabular}

"2" = High School Credential, "3" = Some College, "4" = Bachelor's Degree

Figure 23

\begin{tabular}{|l|c|c|c|c|}
\hline Income, nones & T-Score & Conf. Interval & Mean & P-Value \\
\hline 2012 & 52.90 & $12.41-13.36$ & 12.88 & $2.2 \mathrm{e}-16$ \\
\hline 2020 & 78.30 & $11.30-11.88$ & 11.59 & $2.2 \mathrm{e}-16$ \\
\hline
\end{tabular}

$" 11 "=\$ 60,000-\$ 64,999, " 12 ”=“ \$ 65,000-\$ 69,999 ”, " 13 ”=" \$ 70,000-\$ 74,999 ”$

Figure 24

\begin{tabular}{|l|c|c|}
\hline Sex, nones & Male & Female \\
\hline 2012 & $58.95 \%$ & $41.05 \%$ \\
\hline 2020 & $50.16 \%$ & $49.84 \%$ \\
\hline
\end{tabular}


In 2020, the answers given to the respondents to choose from are broader for the "nones" category, but I thought grouping Mainline Protestant and Evangelical Protestant into a single group in the 2020 survey skewed the data a bit as there is a pretty broad range of Protestants. If we include "Atheists", "Agnostics", and "Nothing In Particular" into our nones for 2020 , we come out with about 32.9 percent of the leaners being nones, compared to 27.4 percent of the general population of the 2020 data set who identify as the same.

Overall, in terms of significance, it appears that over time it has been established that America across all measurements is becoming less religious. In examining the religious scores alone for all of the groups over the eight year time-period, they drop a statistically significant amount to it showing that religion is becoming less important in people's life, they are attending church less frequently, if at all, and other metrics of religiousness.

The surveys did present a difficulty in squaring the differences in response choices, such as in the general religious identification question between the 2012 and 2020 surveys. Whereas the 2012 survey only presented nones with one, or maybe two options, the 2020 survey provided atheist, agnostics, something else, and nothing in particular. Does explicitly mentioning almost "taboo" words in American religious culture such as atheist give nones an out to say "Nothing in Particular" rather than facing what could be a tough choice in the 2012 survey in "No Religion". 
Studying leaners certainly opened a new avenue of exploration in the study of religion and politics in America that I did not expect to examine, but turned out to be incredibly interesting. One of the most interesting aspects of the study into leaners was that while they may have been hesitant to identify themselves with political parties, they were very comfortable and remarkably similar to the general population when asked to place themselves on the ideological scale, i.e. Extremely Liberal-Extremely Conservative. I think it is certainly indicative of the dissatisfaction that the American public seems to show with the two-party system/polarization of American politics and hesitancy to be associated with everything that is attached to a political party in America. 


\section{CHAPTER VI}

\section{CONCLUSION}

Overall, the study provided a lot of interesting information about the continually growing and influential subgroup of the nones in America. America without a common bond of anything but ideals will certainly be an interesting situation to follow. While it could be argued that the American nation has been united by ideals since its inception, it would be naive to say that there has been no partial ethnic or religious bond that helped hold the nation together through its history. An increasingly ethnically diverse America combined with an decreasing religiously unified America certainly poses an interesting challenge for future generations, as we viewed earlier how American political rhetoric is still incredibly religious, could be alienating a larger and larger portion of the American public. It certainly would be interesting to expand the study into the polarization of American politics as the country becomes generally less religious, but as religion still dominates the Republican party. As we saw in some of the results as well, the nones are more Democratic and liberal than the average American, and especially the religious subgroups that came out of the ANES data series. Obviously, either the Democratic party attracts the nones, the Republicans repulse them, or both, and especially in recent years more than in 2012. 
The most interesting aspect of this paper that needs further research certainly came out of the study by Frost and Edgell, who wrote the only piece of research that I found to split the nones up into different subgroups, such as atheist, agnostic, spiritual but not religious, non-religious, or even a subgroup of people who just did not attend church. I think that if more studies follow that approach and it becomes generally accepted in America that the nones are actually a cohort of similar but also quite different belief systems, there may be more acceptance of the group rather than just people who do not like to associate themselves with any group.

An important part of the above statistics is that even though the rise of the nones is increasing rapidly, there is no representation of this sprawling subgroup of the American population in Congress. The last openly atheist member of the American Congress was Representative Pete Stark who stopped serving in 2013. So, even with the large population of nones, where is the representation? It may be that people who identify as nones are indifferent about their representative's religious belief so long as they remain secular when voting and advocating for their constituents. Nonetheless, this subgroup of the American population does not show any signs of slowing down, and it certainly will be a topic that has researchers continuing to look into the phenomenon.

Today, there are no members in Congress who are outed atheists, and there is only one who even identifies as non-religious: Democratic Senator Kirsten Sinema of Arizona, which in 2019 made up 0.2 percent of the Congress, but 23 percent of Americans identify with Senator Sinema in having no religion at all (Pew Forum 2019). If nones were represented in Congress proportionally, there would be 123 nones in Congress. Do the 
American people truly have concern about electing a none to an elected position, or have they just not tried? Gallup has asked this question in their polls, and in 2015, 58\% said they would vote for an atheist as president, and even 60\% said they would in 2019 (McCarthy 2020).

The leaners were an aspect that, at the outset of my research, I did not anticipate incorporating the group into the project, but I found it to be another interesting subgroup of America that appears to also be rising. It could also be a symptom of the increased political polarization, as the competing news outlets, political ads, and general rhetoric seem to attach anything and everything that a single member of a political party or ideological group says to the whole group, and individuals may not want to be associated with the group. For example, moderate Democrats may be more hesitant to identify as a firm Democrat when the news cycle is saying all Democrats want to "defund the police", or Republicans who do not want to associate with the "America First" movement. However, it still appears the leaners vote just as partisan as harder party identifiers. So it's uncertain as to what effects that a growing population of leaners in America will have, but it is certainly another interesting subgroup to follow.

Additionally, more research needs to be done on the nones in different racial groups, both Christian and in other religious traditions, such as Judaism, Islam, Hinduism, etc.. While most of the spotlight in religion in American politics centers on the white Christian population, it would certainly be interesting to see if and how the nones in other religious traditions have been undergoing the same rise and transformation as in 
white America. Especially in the Black Christian community of America, to study if the metrics of behavior and religiosity among Black nones are more or less different than Black Christians. It would also be interesting to explore non-White nones across all demographics as well, to examine if non-White nones are different than White nones.

I knew it would be difficult to track religious activity, beliefs, and behavior to a degree through qualitative measures but I think that separating the religiosity and behavior scores helped determine which subgroups are truly active participants in their religion, and those who are much more internal and individualistic about their religious beliefs. Eisenstein (2006) really focused on capturing those two types of religiousness separately in her study on religion and political tolerance, and it appears to be an important distinction in order to determine how Americans are changing in the religious arena. Just because Americans are not attending church as often does not necessarily mean that religion will be out of politics if Americans still believe in doctrine and that religion plays an important part in their lives. Undoubtedly, things will only become harder and harder to study in the future, but nonetheless will be interesting and integral to understanding the relationship between religion and politics in America. 


\section{REFERENCES}

1. Baker, JO. "Acceptance of evolution and support for teaching creationism in public schools: The conditional impact of educational attainment". Journal for the Scientific Study of Religion 52: 216-228, 2013.

2. Beatty, Kathleen Murphy, and Oliver Walter. "Religious Preference and Practice: Reevaluating Their Impact on Political Tolerance." The Public Opinion Quarterly, vol. 48, no. 1, 1984, pp. 318-329. JSTOR, www.jstor.org/stable/2748626. Accessed 16 Apr. 2021.

3. Campbell, David E., et al. "Putting Politics First: The Impact of Politics on American Religious and Secular Orientations." American Journal of Political Science, vol. 62, no. 3, 2018, pp. 551-565., doi:10.1111/ajps.12365.

4. Dionne, E.J. "Opinion | Churchgoers, Cut the 'Chreasters' Some Slack." The Washington Post. WP Company, December 24, 2018. https://www.washingtonpost.com/opinions/churchgoers-cut-the-chreasters-some-s lack/2018/12/23/53822ca4-0645-11e9-b5df-5d3874f1ac36_story.html.

5. Drutman, Lee. "The Moderate Middle Is A Myth." FiveThirtyEight, FiveThirtyEight, 24 Sept. 2019, fivethirtyeight.com/features/the-moderate-middle-is-a-myth/.

6. Eisenstein, Marie. "Rethinking the Relationship between Religion and Political Tolerance in the US". Political Behavior, 28. 327-348, 2006. 10.1007/s11109-006-9014-5.

7. Ellison, C. G., \& Musick, M. A. "Southern intolerance: A Fundamentalist Effect?" Social Forces, 72(2), 379-398, 1993. doi:10.1093/sf/72.2.379

8. Filsinger, Erik. "Tolerance of Non-Believers: A Cross-Tabular and Log Linear Analysis of Some Religious Correlates." Review of Religious Research, vol. 17, no. 3, 1976, pp. 232-240. JSTOR, www.jstor.org/stable/3510614.

9. Froese, P., C. Bader, and B. Smith. "Political Tolerance and God's Wrath in the United States." Sociology of Religion 69.1, 2008: 29-44. 2008. Web.

10. Frost, Jacqui, and Penny Edgell. "Rescuing Nones From the Reference Category: Civic Engagement Among the Nonreligious in America." Nonprofit and Voluntary Sector Quarterly, vol. 47, no. 2, 2017, pp. 417-438., doi:10.1177/0899764017746251.

11. Gill, Anthony. "Religion and Comparative Politics." Annual Review of Political Science 4.1, 117-38. 2001, Web.

12. Hout, Michael, and Claude Fischer. "Explaining Why More Americans Have No Religious Preference: Political Backlash and Generational Succession, 
1987-2012." Sociological Science, vol. 1, 2014, pp. 423-447., doi:10.15195/v1.a24.

13. Hout, Michael, and Claude S. Fischer. "Why More Americans Have No Religious Preference: Politics and Generations." American Sociological Review, vol. 67, no. 2, 2002, p. 165., doi:10.2307/3088891.

14. Hughes, C. "The God card: Strategic employment of religious language in U.S. presidential discourse." International Journal of Communication, 13, 2019. https://ijoc.org/index.php/ijoc/article/view/8484/2547

15. Jennings, Jay T. "Mixed Reactions: How Religious Motivation Explains Responses to Religious Rhetoric in Politics." Political Research Quarterly, vol. 69, no. 2, June 2016, pp. 295-308, doi:10.1177/1065912916636690.

16. Jones, Jeffrey M. "U.S. Church Membership Down Sharply in Past Two Decades." Gallup.com, Gallup, 6 Apr. 2021, news.gallup.com/poll/248837/church-membership-down-sharply-past-two-decade s.aspx.

17. Jones, Jeffrey M. "U.S. Church Membership Falls Below Majority for First Time.” Gallup.com, Gallup, 29 Mar. 2019, news.gallup.com/poll/341963/church-membership-falls-below-majority-first-time .aspx.

18. Katnik, Amy. "Religion, Social Class, and Political Tolerance". International Journal of Sociology, 32:1, 14-38, 2002, DOI: 10.1080/15579336.2002.11770242

19. Klar, Yanna Krupnikov and Samara. "Why People Call Themselves 'Independent' Even When They Aren't.” The Washington Post, WP Company, 3 May 2019, www.washingtonpost.com/news/monkey-cage/wp/2014/01/10/why-people-call-th emselves-independent-even-when-they-arent/.

20. Lusthaus, Jonathan. "The God Strategy: How Religion Became a Political Weapon in America" Journal of Religious History 34.4, 485-87, 2010. Web.

21. Magleby, David B., and Candice Nelson. "Independent Leaners as Policy Partisans: An Examination of Party Identification and Policy Views." The Forum, vol. 10, no. 3, 2012, doi:10.1515/1540-8884.1522.

22. McCarthy, Justin. "Less Than Half in U.S. Would Vote for a Socialist for President." Gallup.com, 23 Nov. 2020, news.gallup.com/pol1/254120/less-half-vote-socialist-president.aspx.

23. Putnam, Robert D., et al. Making Democracy Work: Civic Traditions in Modern Italy. Princeton Univ. Press, 1993.

24. Schmidt, Erik. "U.S. Population More Educated Than Ever Before." The United States Census Bureau, July 16, 2019. https://www.census.gov/library/stories/2018/07/educational-attainment.html.

25. Stouffer, Samuel Andrew. Communism, Conformity and Civil Liberties: A Cross-section of the Nation Speaks Its Mind. New Brunswick: Transaction, 2009. Originally published 1955 . Print. 
26. Torpey, Elka. "Measuring the Value of Education : Career Outlook." U.S. Bureau of Labor Statistics. April 2018.

https://www.bls.gov/careeroutlook/2018/data-on-display/education-pays.htm.

27. Tuchfarber, Alfred J., et al. "The Republican Tidal Wave of 1994: Testing Hypotheses about Realignment, Restructuring, and Rebellion." PS: Political Science and Politics, vol. 28, no. 4, 1995, pp. 689-696. JSTOR, www.jstor.org/stable/420519.

28. Wilcox, Clyde, and Ted Jelen. "Evangelicals and Political Tolerance." American Politics Quarterly, vol. 18, no. 1, Jan. 1990, pp. 25-46, doi:10.1177/1532673X9001800102.

29. Zuckerman, Miron, Jordan Silberman, and Judith A. Hall. "The Relation Between Intelligence and Religiosity." Personality and Social Psychology Review 17, no. 4 325-54, 2003. https://doi.org/10.1177/1088868313497266.

30. "2012 Time Series Study - ANES: American National Election Studies." ANES | American National Election Studies, May 28, 2015.

https://electionstudies.org/data-center/2012-time-series-study/.

31. "2020 Time Series Study - ANES: American National Election Studies." ANES | American National Election Studies, 24 Mar. 2021 electionstudies.org/data-center/2020-time-series-study/.

32. "In America, Does More Education Equal Less Religion?" Pew Research Center's Religion \& Public Life Project, April 26, 2017.

https://www.pewforum.org/2017/04/26/in-america-does-more-education-equal-les s-religion/.

33. "In U.S., Decline of Christianity Continues at Rapid Pace." Pew Research Center's Religion \& Public Life Project. December 31, 2019. https://www.pewforum.org/2019/10/17/in-u-s-decline-of-christianity-continues-at -rapid-pace/.

34. "Religion in America: U.S. Religious Data, Demographics and Statistics." Pew Research Center's Religion \& Public Life Project. May 11, 2015. https://www.pewforum.org/religious-landscape-study/.

35. "Religious Organizations Seen as Forces for Good in U.S." Pew Research Center's Religion \& Public Life Project, 5 May 2020, www.pewforum.org/2019/11/15/many-in-u-s-see-religious-organizations-as-force s-for-good-but-prefer-them-to-stay-out-of-politics/.

36. “"Nones' on the Rise." Pew Research Center's Religion \& Public Life Project, Pew Research Center, 30 May 2020, www.pewforum.org/2012/10/09/nones-on-the-rise/. 


\section{CURRICULUM VITA}

NAME:

ADDRESS:

EDUCATION

\& TRAINING:
Kevin Connelly Orr

University of Louisville 2392 S. 3rd St.

Louisville, KY 40292

Cincinnati, OH - June 5, 1995

B.A. International Studies Allegheny College 2013-2017

M.A. Political Science University of Louisville 2019-2021 